\title{
Identification of Reproductive Activity of Donggala Cattle at Post Puberty and Post Partum Periods
}

\author{
Ismail Wumbu* \\ Department of Animal Husbandry, University of Tadulako, Indonesia \\ B. Sundu \\ Department of Animal Husbandry, University of Tadulako, Indonesia \\ Rusdin Dien \\ Department of Animal Husbandry, University of Tadulako, Indonesia \\ Najamudin \\ Department of Animal Husbandry, University of Tadulako, Indonesia \\ Miradjuddin \\ Department of Animal Husbandry, University of Tadulako, Indonesia
}

\begin{abstract}
The aim of the study is to investigate condition and reproductive activity of Donggala cattles during post-puberty and post-partom periods. The study was carried out for 12 months at Donggala, Palu and Sigi Districts where major populations of Donggala cattles were kept by farmers. A total of 200 heads of Donggala cattles belonged to the local farmers were sampled. The animals were categorized as heifers when they were $10-18$ months old and cows at $18-24$ months old. Data colected inthis study were from structured interview and direct observation. Variables measured were body condition score, live body weight, age of puberty, age of first estrus and first mating, days open, service per conception rate, non return rate and conception rate either during post puberty or post partum. Data found in this study were describe descriptively. The results of the study indicated that the age of puberty was late as live body weight body condition score of Donggala were low. First mating of Donngala heifers was much dependant upon live body weight. Heavier cattles tended to mat earlier than the lighter cattles. Heavier catlles had better service per conception rate, non return rate and conception rate either at post puberty or post partum periods. In conclusion, the cows with high body weight had earlier first estrus, first mating and better service per conception rate, non return rate and conception rate than those cows with low live body weight. Keywords: Donggala cattle, reproductive efficiency, post puberty, post partum
\end{abstract}

DOI: $10.7176 / \mathrm{JBAH} / 9-6-05$

Publication date:March $31^{\text {st }} 2019$

\section{Introduction}

The Government of Central Sulawesi Province, Indonesia began to develop two types of local livestock in 2015 that have received certification and recognition from the central government of Indonesia. Two types of the certified local livestock are Palu sheep and Donggala cattle. Since then The Central Sulawesi government developed a program to increase the Donggala cattle population at Palu City, Sigi and Donggala Regencies. Donggala cattle have advantages over Bali cattle, such as higher growth (body weight gain), lower conception failure rates and lower fetal mortality than Bali cattle (Hamsun and Padang, 2010).

Donggala cattle receiving recognition from the Ministry of Agriculture of the Republic of Indonesia have their own specific characteristics, so the government made Donggala cattle as one of the priority to be developed in animal husbandry sector. Donggala cattle as a germ plasm in central Sulawesi need to be conserved. Accordingly, studies must be carried out to obtain an appropriate development method to accelerate Donggala cattle population by implementing a package of reproductive technology and breeding program.

Reproduction is a complex process through various stages before the reproductive cycle begins after the animals are born. During growth, reproductive system undergoes development until a certain age when sexual organs are fully developed and functional. Once the cattle get into sexual maturity, this phase is called puberty. Delayed puberty in cattle industry might create problem because puberty of early age of cattle could produce more calves. A lot of factors can directly or indirectly affect growth, puberty and sexual maturity and those factors are nutrition, health, hormones and management. Hence, a study was carried out to investigate the age of puberty, estrus and the ideal body weight for first mating, first estrus, days open, service per conception, non return rate and conception rate of Donggala cattle at post puberty and past partum periods. 


\section{Materials and Methods}

\subsection{Time, location and animals of research}

The study was conducted at three locations (Donggala, Palu and Sigi Districts). These three districts are the main places where Donggala cattle were kept. This research was conducted for 12 months. The Cattles sampled in this study were 200 heads with five different categories based on body condition scores. The value of body condition scores were from 1 to 5 in which score 1 was thin, score $3=$ medium and score $5=$ fat. This categorization was based on Spitcer, (2001).

\subsection{Parameters measured}

Data collection of reproductive activities of Donggala heifers during the prost puberty period were focused on body weight, body condition score, first estrus, first mating, service per conception, non return rate and conception rate. Data of first mating was taken when the animals showed estrus and had natural mating. Data on age of firs mating was calculated from the number of days starting from the day of delivery until the first day mating. This data were associated with service per conception, Non Return Rate, and Conception Rate after mating (Bearden, 1980).

Conception rates were calculated based on the number of heifers who did not return after artificial insemination. Determination of conception rates pregnancy rates after estrus detection was done on days 42, 49, and 60 after artificial insemination (Bearden, et al., 2004) by direct observation of estrus signs and / or by inserting male cattles in female groups in those days. If it did not show estrus symptoms or did not return to request mating, then it was called pregnant. Data on the conception rate percentage of the first artificial insemination were calculated using the formula Bearden, et al. (2004) and Hafez (2000).

Data collection was done on reproductive activity of Donggala cow in the post partum period. Observations were emphasized on variables that are directly related to the condition or reproductive cycle during the postpartum period until they are re-mated normally. The research variables observed were: body weight, body condition score, days open, service per conception rate, non return rate and conception rate of Donggala cow in post partum period. Measurements and observations of days open were done based on the return of the cows to normal and good conception in one post-partum mating period (Ball and Peters, 2004). Days open was set in units of time "days" starting from the day of delivery until they were re-mated and conception.

\subsection{Research design}

Research design used was descriptive research with structured interview and direct observation (Sugiyono, 2008). Data were collected by purposive sampling and accidental sampling, especially for data with a limited population. All data collected in this study were elaborated descriptively.

\section{Results and Discussion}

\subsection{Results}

Data on BCS, age of puberty, first estrus age, first mating, service perconception, non return rate dan conception rate at post puberty period were shown in Table 1. Data on body condition score, body weight, days open, service perconception, non return rate dan conception rate at post partum period were shown in Table 2 .

\subsection{Discussion}

\subsubsection{Conditions and reproductive activity of the Donggala cows in Post-puberty period}

The results of the study on reproductive activity of Donggala heifers at the post puberty period based on body condition score indicated that puberty in heifers with the appearance of first estrus normally followed the luteal phase (Jainudeen and Hafez, 2008). Puberty in heifers was specific as a physiological activity that is directly related to age (Jainudeen and Hafez, 2008) and weight. Puberty in cows is influenced by many factors, such as age, body weight, and body condition score.

The results of the present study showed that the age of puberty was getting late with lower body weight and body condition score of Donggala heifers (Table 2). Donggala cattle with body condition score 2 kept in Donggal districs had puberty age on day 623 and first estrus with an average body weight of $182 \mathrm{~kg}$. The puberty age of Donggala cattles was too late, compared to beef cattle. Normally the age of puberty for beef cattle was 10 12 months (300 - 360 days) but Zebu experienced puberty at the age of 18-24 months (Jainudeen and Hafez, 2008). This condition might had direct relation to the quality of feed consumed as the diets could facilitate for optimal growth of heifers to meet the onset of first estrus (puberty). This initial puberty or estrus condition determined the proper time to have high level of success rate for first mating. The age and initial optimal weight to mat Donggala cattle were an average of 652 days and $252.75 \mathrm{~kg}$ respectively (Table 5) with an average conception rate of $75 \%$. The delay in first estrus and first mating in Donggala heifers with body condition score of 2, compared to body condition score of 3 and 4 was caused by variations in body condition and initial body weight. Variations in body conditions that cause delays in the appearance of estrus and early mating time was 
due probably to variations in nutrients obtained during the initial growth since post partum until puberty. This condition also possibly affected ovarian activity normally. Ovarian activity was influenced by several factors, such as nutrition, breeds, maintenance management, environment and body composition.

The success rate of first mating in the post puberty period was measured by non retun rate and conception rate. The reproductive efficiency of post puberty of Donggala heifers was related to body condition and initial mating. The efficiency was based on the number of mating to make heifers truly pregnant (service per conception). The percentage of non return rate and conception rate of Donggala heifers during the post puberty period increased with improvement in body condition score and increased body weight at the first mating. Donggala heifers with body condition score of 4 and 3 showed higher non return rate and conception rate being 100 and 75 to $90 \%$ respecitvely (Table 3), compared to those with body condition score of 2 (67 and 33\%). Percentage of non return rate and conception of Donggala heifers found in the present study reflected the level of reproductive efficiency and effectiveness of first mating. To get the good percentage of pregnancy and service per conception is by calculating body condition score and initial body weight.

\subsubsection{Conditions and reproductive activity of the Donggala cows in Post-partum period}

The results of the study on the reproductive activity of the Donggala cows in the post partum period showed that the heavier body weight of Donggala cows, the shorter the days open period. Donggala cows which had body condition score 3 and 4 had a short days open. The cows with body condition score of 3 and 4 also produced better results with the value of service per conception of 1.25 and 1,10 , non return rate of $100 \%$ for both and conception rate of $75 \%$ and $90 \%$ respectively. Good body condition was very closely related to the process of returning the uterus in its original state (uterine involution). In cattle with good nutritional conditions, the process of uterine involution reached an average of 45 days (Hafez, 2000). The speed of process of uterine involution greatly affected the reproductive efficiency of an animal. Feed is one factor in achieving the reproductive efficiency of an animal. Feed is a very important factor because without nutritious feed, high performance of animal could not be achieved although the animals were derived from good strains. It needs high quality feed to support growth and reproduction. Adequate nutrition during the recovery process would speed up the re-mating and in the end calving interval was getting shorter (Aziz, et al., 2010; Abdallah, 2003; Bag, et al., 2010).

Short calving interval is associated with ovarian activity after calving. This is preceded by a process of uterine involution which runs normally due to the good condition of the body for meeting maintanance and reproduction. Nutritional adequacy shown by livestock with body condition score of 3 and 4 resulted in a normal ovarian activity, estrus and ovulation (Hafez, 2000; Perera, 2011; Mouffok, et, al., 2011; Roche, et, al., 2015). The period of uterine involution can run normally if it was supported by adequate nutrition (Yindee, et, al., 2007; Borghese, 2010).

Donggala cows with body condition score 2 and a live weight of $236 \mathrm{~kg}$ had 95 days open. The quite long days open was partly due to the condition of thin animals with limited nutritional needs. This condition resulted in nutrients requirement for reproduction become unmanagable which will disrupt production and reproduction activity. Adequate nutrition in the postpartum period is needed for production for the young calves, to compensate growth and uterine involution to prepare for the next pregnancy (Peters and Ball, 2004).

\section{CONCLUSIONS}

Based on the results of the research, it can be concluded as follows:

1. The first puberty and estrus of Donggala cattle with body condition score of 3 and an average body weight of $247 \mathrm{~kg}$ occurred at an average age of 565 days or 18.83 months.

2. The optimum age and body weight for first mating of Donggala cattle was 652 days and $252.75 \mathrm{~kg}$ with $75 \%$ conception rate and service per conception of $1.25 \%$.

3. The days open for the post partum period of Donggala cattle with body condition score of 3 and the average body weight of $277 \mathrm{~kg}$ was 70 days

\section{References}

Abdallah, E. B., 2003. Improvement the Reproductive Performance of Egyptian Buffalo Cow by Changing the Management System. Animal Reproduction Science, 75 (1-2): 1-8.

Aziz, M. A., Schoeman, S. J., G.F.J. El-Chafie, O.M. and A.T.M., 2010. Genetic and Phenotypic Variation of Some Reproductive Traits in Egyptian Buffalo. South African Journal of Animal Science 31(3): 195-199.

Ball, P.J.H and Peters, A.R., 2004. Reproduction In Cattle. Third Edition. Blackwell Publishing.Victoria. Australia. De Vries, A. 2006. Determinants of the cost of days open in dairy cattle. Department of Animal Sciences. University of Florida. Gainesville 32611. USA.

Bag, S., Mehre, P.V. and Majumdar, A.C., 2010. Effect of Season on Oocyte Maturation and Embryo Development in Buffalo. Indian Journal of Animal Science, 80(7): 618-620.

Bearden, H.J. and J.W. Fuquay. 1980. Applied Animal Reproduction. Reston Publishing Co., Inc. Prentice Hall 
Co. Reston Virginia.

Bearden, J. H., J.W. Fuquay, and S.T. Willard, 2004. Applied Animal Reproduction, $6^{\text {th }}$ edition, Prentice-Hall Inc., New Jersey.

Borghese, A., 2010. Development and Perspective of Buffalo and Buffalo Market in Europe and Near East. Proceedings 9th World Buffalo Congress, Buenos Aires, 25-28 April. Revista Veterinaria 21(1): 20-31.

Hafez, E. S. E., 2000. Semen Evaluation. In: Reproduction In Farm Animals. 7 the Edition. Lippincott Wiliams and Wilkins. Maryland. USA

Hamsun, M. dan Padang, 2010. Identifikasi sapi Donggala sebagai plasma nutfah sapi asli Sulawesi Tengah. Laporan Penelitian. Dinas Peternakan dan Kesehatan Hewan Daerah Provinsi Sulawesi Tengah.

Jainudeen, M.R. and Hafez, E.S.E., 2008. Cattle And Buffalo. In: Reproduction In Farm Animals. 7th Edition. Edited by Hafez E. S. E. Lippincott Williams \& Wilkins. Maryland. USA.

Mouffok, C., Smara, L., Madani, E., Debeche, H. and Belkasmi, F., 2011. Relationship Between Body Condition Score, Body Weight, Some Nutritional Metabolites Change in Blood and Reproduction in Algerian Montbeliad Cow. Veterinary World, 4(10): 461-466.

Perera, B.M., 2011. Reproductive Cycles of Buffalo. Animal Reproduction Science 124(3-4) 194-199.

Petters, A.R. and Ball, P.J.H., 2004. Reproduction in Cattle ( $3^{\text {rd }}$ ed.). Garsington Road, Oxford OX4 2DQ, United Kingdom: Blackwell Publishing Ltd.

Roche, J.R.S.M., Heiser, A., Mitchell, M.D., Walker, C.G., Crookenden, M.A., Riboni, M.V., Loor, J.J. and Kay, J.K., 2015. Effect and Pre-calving Body Condition Score and Pre-partum Feeding Level on Production, Reproduction, and Health Parameters in Pasture-Based Transition Dairy Cow. Journal Dairy Science 98(10) 7164-7182.

Spitcer, J.C., 2001. Body Condition Score and Reproduction in Beef Cows. http://gpvpc.untedu/and 520 Repro\%2022001.

Sugiyono. 2008. Metode Penelitian Kuantitatif Kualitatif dan R\&D. Bandung : Alfabeta.

Yindee, M., Techakumphu, M., Lohachit, C., Siriavaidyapong, S., Na-Chiangmai, A. and Colenbrander, B. 2007. Ovarian Activity and Sexual Behavior in the Pospartum Swamp (Babalus bubalis). Italian Journal Animal Science 6 (supplement 2): 632-535.

Table 1. Average of body condition score, age of puberty, first estrus, first mating, service per conception rate, non return rate and conception rate of Donggala heifer at post puberty period

\begin{tabular}{lllllllll}
\hline \multirow{2}{*}{ No. } & \multirow{3}{*}{$\begin{array}{l}\text { BCS } \\
(\mathrm{kg})\end{array}$} & & weight & \multicolumn{2}{l}{ Age (days) } & \multicolumn{3}{c}{ First Mating } \\
\cline { 5 - 9 } & & & Puberty & First Estrus & $\begin{array}{l}\text { First } \\
\text { Mating }\end{array}$ & S/C & $\begin{array}{l}\text { NRR } \\
(\%)\end{array}$ & CR (\%) \\
\hline 1 & $2 *$ & 182 & 623 & 623 & 689 & 1,67 & 67 & 33 \\
2 & $3^{* *}$ & 247 & 565 & 565 & 607 & 1,25 & 100 & 75 \\
3 & $4 * * *$ & 272 & 557 & 557 & 579 & 1,10 & 100 & 90 \\
\hline
\end{tabular}

*Number of cattle: 93 ; ** number of catlle 101 and ***number of cattle: 6 heads

$\mathrm{S} / \mathrm{C}$ : Service per conception; NRR: non return rate; CR: Conception rate

Table 2. Body Weight, body condition score, days open, service per conception, non return rate, and conception rate of Donggala cows post partum period

\begin{tabular}{|c|c|c|c|c|c|c|c|c|}
\hline \multirow[b]{2}{*}{ No. } & \multirow[b]{2}{*}{ BCS } & \multirow{2}{*}{$\begin{array}{l}\text { Body } \\
\text { (Kg) }\end{array}$} & \multirow[t]{2}{*}{ weight } & \multirow{2}{*}{$\begin{array}{l}\text { Days } \\
\text { (day) }\end{array}$} & \multirow[t]{2}{*}{ Open } & \multicolumn{3}{|c|}{ First Mating Post Partum } \\
\hline & & & & & & $\mathbf{S} / \mathbf{C}$ & NRR (\%) & CR (\%) \\
\hline 1 & $2 *$ & 236 & & 95 & & 1,67 & 67 & 33 \\
\hline 2 & $3 * *$ & 277 & & 70 & & 1,25 & 100 & 75 \\
\hline 3 & $4 * * *$ & 291 & & 62 & & 1,10 & 100 & 90 \\
\hline
\end{tabular}

*Number of cattle: $93 ; * *$ number of catlle 101 and $* * *$ number of cattle: 6 heads

$\mathrm{S} / \mathrm{C}$ : Service per conception; NRR: non return rate; CR: Conception rate 